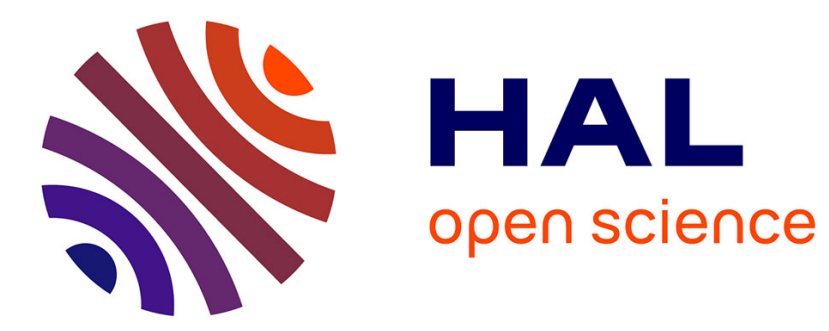

\title{
Spirolides and Cyclic Imines: Toxicological Profile
}

Jordi Molgó, Evelyne Benoit, Rómulo Aráoz, Armen Zakarian, Bogdan Iorga

\section{To cite this version:}

Jordi Molgó, Evelyne Benoit, Rómulo Aráoz, Armen Zakarian, Bogdan Iorga. Spirolides and Cyclic Imines: Toxicological Profile. Marine and Freshwater Toxins, Springer Netherlands, pp.193-217, 2016, 10.1007/978-94-007-6419-4_23. hal-02334618

\section{HAL Id: hal-02334618 \\ https://hal.science/hal-02334618}

Submitted on 8 Mar 2021

HAL is a multi-disciplinary open access archive for the deposit and dissemination of scientific research documents, whether they are published or not. The documents may come from teaching and research institutions in France or abroad, or from public or private research centers.
L'archive ouverte pluridisciplinaire HAL, est destinée au dépôt et à la diffusion de documents scientifiques de niveau recherche, publiés ou non, émanant des établissements d'enseignement et de recherche français ou étrangers, des laboratoires publics ou privés. 


\section{SPIROLIDES AND OTHER CYCLIC IMINE TOXINS: TOXICOLOGICAL PROFILE}

Jordi Molgó $^{1 * a}$, Evelyne Benoit ${ }^{1 a}$, Rómulo Aráoz ${ }^{1 a}$, Armen Zakarian ${ }^{2}$ and Bogdan I. Iorga ${ }^{3 *}$

${ }^{1}$ CNRS, Institut de Neurobiologie Alfred Fessard - FRC 2118, Laboratoire de Neurobiologie et Développement - UPR 3294, 1 avenue de la Terrasse, bâtiments 32-33, F-91198 Gif-sur-Yvette Cedex, France.

${ }^{2}$ Department of Chemistry and Biochemistry, University of California, Santa Barbara, California 93106, USA.

${ }^{3}$ CNRS, Institut de Chimie des Substances Naturelles, UPR 2301, Labex LERMIT, F-91198 Gifsur-Yvette Cedex, France.

a Present address : CEA, Institut de Biologie et Technologies de Saclay (iBiTec-S) Service d'Ingénierie Moléculaire des Protéines (SIMOPRO), Laboratoire de Toxinologie Moléculaire et Biotechnologies (LTMB), bâtiment 152, courrier N² 24, 91191 Gif-sur-Yvette, France

* authors for correspondence

E-mail: Jordi.Molgo@inaf.cnrs-gif.fr; Phone: +33 169823642 ; Fax : +33 169823447

E-mail: Bogdan.Iorga@cnrs.fr ; Phone: +33 169823094 ; Fax : +33 169077247

\section{$\underline{\text { ABSTRACT }}$}

In this chapter, we review available evidence on the toxicological profile of spirolides and other lipophilic cyclic imine toxins, highlighting their chemical structure, the phytoplankton species involved in their production, their pharmacokinetics/toxicokinetics and experimental toxicity, and their molecular targets and mechanisms of action. These phycotoxins belong to an emerging class of chemical agents associated with marine algal blooms and shellfish toxicity. Their chemical structure is represented by a macrocycle, with the ring size between 14 and 27, and two conserved features that include the cyclic imine group and spiroketal ring system. The producers of spirolides, gymnodimines and pinnatoxins have been identified as being the dinoflagellates Alexandrium ostenfeldii/peruvianum, Karenia selliformis and Vulcanodinium rugosum. Their acute toxicity, 
appraised by the mouse bioassays, classifies them as "fast-acting" toxins because they induced rapid onset of neurological symptoms followed by death within a few minutes. The spirolide congeners are the most toxic after intraperitoneal injection, while there are indications that pinnatoxins are the most toxic group after oral administration. The neurotoxic effects reported for these phycotoxins are mostly due to their specific interaction with the muscle- and neuronal-types of nicotinic acetylcholine receptors which are the principal molecular targets of spirolides, gymnodimines and pinnatoxins, so far studied. Hence, these phycotoxins exhibit both high affinity and broad specificity on nicotinic receptors, indicating that their sites of interaction in the receptors include amino acid residues highly conserved among animal species.

\section{INTRODUCTION}

Spirolides were first discovered in the 1990s from the Atlantic coast of Nova Scotia in Canada when unusual toxicities were detected by mouse bioassay in mussel and scallop extracts. Since then, the spirolides have been found to have a worldwide distribution, with a remarkable diversity in their chemical profiles. Spirolides belong to the so-called cyclic imine group of neurotoxins that also include the gymnodimines, pinnatoxins, pteriatoxins, portimine, spiro-prorocentrimine and prorocentrolides (for a recent review, see Stivala et al., 2015). The generic chemical structure of the cyclic imine toxins is represented by a macrocycle, with the ring size between 14 and 27, and two conserved features that include two subunits: the cyclic imine group (which in most cases is found as a spiroimine) and the spiroketal ring system. The cyclic imine, which has been shown to be a key pharmacophoric feature, can be a 5-membered (portimine), 6-membered (gymnodimines, spiroprorocentrimine, prorocentrolides) or 7-membered (spirolides, pinnatoxins, pteriatoxins) ring, that in many cases is substituted with one or two methyl groups. The spiroketal ring system can be a simple tetrahydrofuran (i.e. portimine, gymnodimine) or tetrahydropyran group (i.e. spiroprorocentrimine, prorocentrolides), but also a more complex 6,5- (spirolides $\mathrm{H}$ and I), 6,6,5(spirolide G), 6,5,5- (spirolides A-F) or 6,5,6-spiroketal (pinnatoxins, pteriatoxins).

\section{Figure 1 near here}




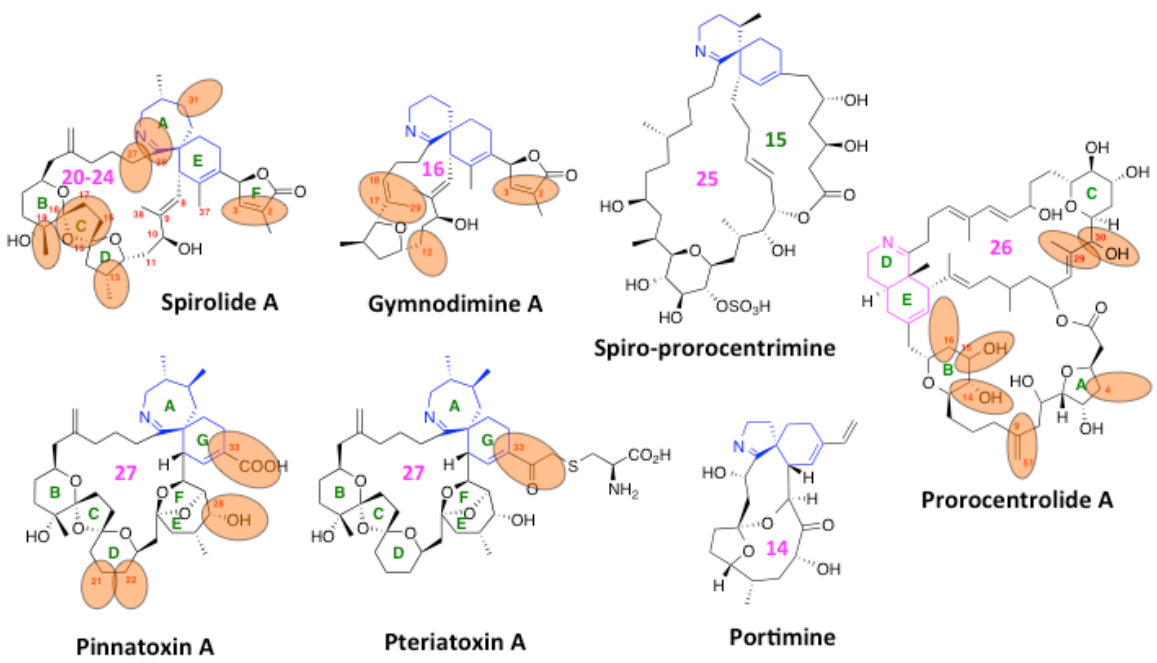

Figure 1. Chemical structures of the spiroimine toxins. For each sub-family, the first member is shown and the positions for which variations in the substitution pattern were reported are numbered and highlighted in orange. The characteristic spiroimine and cyclic imine features are colored in blue and magenta, respectively, and the size of the macrocyclic ring system in each sub-family is shown in magenta.

Spirolides and the cyclic imine toxins studied so far are "fast-acting" phycotoxins, because of the rapid beginning of neurological symptoms and the short time to death. The basis for these neurotoxic effects is in direct relation to their molecular antagonist action on nicotinic acetylcholine receptors. In this chapter, we summarize our current understanding of the toxicological profile of spirolides and other cyclic imine toxins, with emphasis on their chemical structure, producing organisms, pharmacokinetics/toxicokinetics, experimental toxicity, molecular targets and mechanism of action.

\section{SPIROLIDES}

\section{- Chemical characteristics of spirolide toxins}

Spirolides constitute the largest family among cyclic imine toxins. As shown in Figure 2, to date sixteen spirolide analogues have been reported, which can be classified into four distinct groups according to the structure of the spiroimine and spiroketal ring systems. The first group of spirolides has 10 members with a characteristic 6,5,5-spiroketal ring system. As compared to spirolides A and $\mathrm{B}$, the spirolides $\mathrm{C}$ and $\mathrm{D}$ and their analogues have an extra methyl group at the position 31 on the imine ring, which is believed to render them more resistant to enzymatic and acidic hydrolysis (Christian et al., 2008). Spirolides A and C and their analogs have a double bond between the positions 2 and 3 on the lactone ring which is not present in the structure of spirolides B and D and their derivatives. Other positions where structural variability was observed for spirolides C and D are 13 and 19 on the spiroketal ring system, with the presence or absence of methyl substituents, and 27, where hydroxy and keto substituents were evidenced in some cases. The second spirolide 
group contains the biologically inactive spirolides $\mathrm{E}$ and $\mathrm{F}$, which present the same chemical features as spirolides A and B, respectively, except for the cyclic imine that becomes an open ring amino ketone (reviewed by Guéret and Brimble, 2010). These structural changes suggest that they are probably shellfish metabolites of spirolides A and B. The third spirolide group, represented by spirolide-G and 20-methyl spirolide-G, has a 6,6,5-spiroketal ring system with a hydroxyl group at C17 for which the stereochemistry could not be determined (MacKinnon et al., 2006) and a methyl substituent at C20 that is present only in the second member of this group. The rest of the structure is identical with spirolide-C, with the dimethyl substituted 7-membered cyclic imine and the unsaturated lactone ring. The fourth spirolide group includes spirolides $\mathrm{H}$ and I whose structures are identical to spirolides $\mathrm{C}$ and $\mathrm{D}$, respectively, apart from the presence of a 6,5- instead of the 6,5,5spiroketal ring system (Roach et al., 2009). Spirolide-H is the 2,3-unsaturated counterpart of spirolide I.

Figure 2 near here

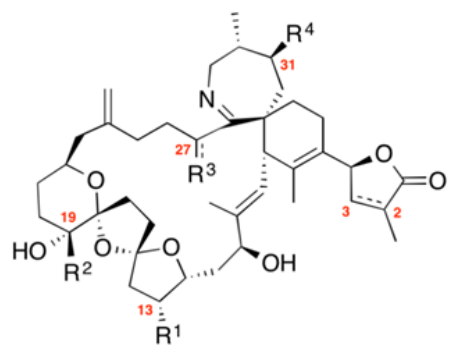

\begin{tabular}{lccccc} 
Spirolide & $\boldsymbol{\Delta}$ & $\mathbf{R}^{\mathbf{1}}$ & $\mathbf{R}^{\mathbf{2}}$ & $\mathbf{R}^{\mathbf{3}}$ & $\mathbf{R}^{\mathbf{4}}$ \\
\hline Spirolide-A & $\Delta^{2,3}$ & $\mathrm{CH}_{3}$ & $\mathrm{CH}_{3}$ & $\mathrm{H}$ & $\mathrm{H}$ \\
Spirolide-B & - & $\mathrm{CH}_{3}$ & $\mathrm{CH}_{3}$ & $\mathrm{H}$ & $\mathrm{H}$ \\
Spirolide-C & $\Delta^{2,3}$ & $\mathrm{CH}_{3}$ & $\mathrm{CH}_{3}$ & $\mathrm{H}$ & $\mathrm{CH}_{3}$ \\
Spirolide-D & - & $\mathrm{CH}_{3}$ & $\mathrm{CH}_{3}$ & $\mathrm{H}$ & $\mathrm{CH}_{3}$ \\
13-desmethyl spirolide C & $\Delta^{2,3}$ & $\mathrm{H}$ & $\mathrm{CH}_{3}$ & $\mathrm{H}$ & $\mathrm{CH}_{3}$ \\
13-desmethyl spirolide D & - & $\mathrm{H}$ & $\mathrm{CH}_{3}$ & $\mathrm{H}$ & $\mathrm{CH}_{3}$ \\
13,19-didesmethyl spirolide C & $\Delta^{2,3}$ & $\mathrm{H}$ & $\mathrm{H}$ & $\mathrm{H}$ & $\mathrm{CH}_{3}$ \\
27-hydroxy-13 desmethyl spirolide C & $\Delta^{2,3}$ & $\mathrm{H}$ & $\mathrm{CH}$ & $\mathrm{OH}$ & $\mathrm{CH}_{3}$ \\
27-hydroxy-13,19-didesmethyl spirolide C & $\Delta^{2,3}$ & $\mathrm{H}$ & $\mathrm{H}$ & $\mathrm{OH}$ & $\mathrm{CH}_{3}$ \\
27-oxo-13,19-didesmethyl spirolide C & $\Delta^{2,3}$ & $\mathrm{H}$ & $\mathrm{H}$ & $\mathrm{O}=$ & $\mathrm{CH}_{3}$
\end{tabular}
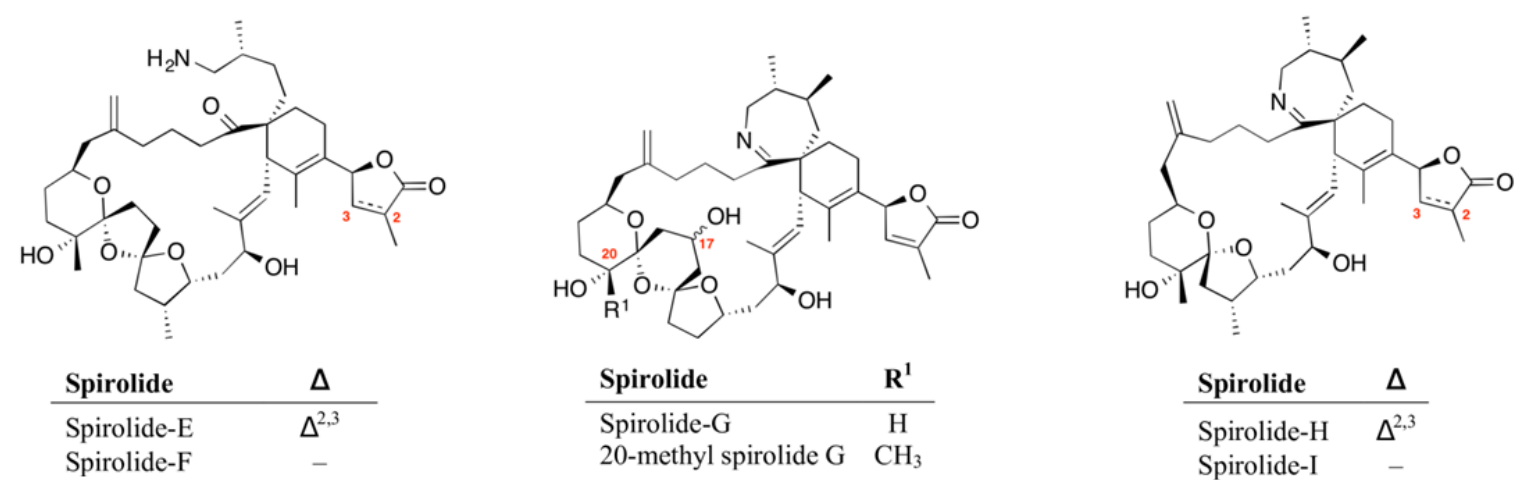

Figure 2. Chemical structures of the known spirolide toxins.

\section{- Spirolide producing organisms}

The producers of spirolides and other cyclic imine toxins were identified as dinoflagellates, a large and diverse group of marine eukaryotic microalgae known to be the major causative agents of harmful algal blooms. Although many dinoflagellate species can produce various natural toxins that impact humans, those involved in the production of Cyclic Imine toxins are limited to mainly Alexandrium, Karenia (formely Gymnodinium), Vulcanodinium and Prorocentrum species (for reviews, see Molgó et al., 2014a; Stivala et al., 2015). 
All known spirolides have been so far linked to Alexandrium species, and differences in spirolides content and profiles have been reported for dinoflagellate strains from different coastal regions. Hence, the globally distributed species Alexandrium ostenfeldii (Cembella et al., 1999) was formerly identified as the biological source of all known spirolides (Table 1). However, during the past six years, another dinoflagellate species, Alexandrium peruvianum, was also recognized as the producing organism for some spirolide congeners in Northwestern Mediterranean Sea waters, Irish coastal waters (Touzet et al., 2008) and in the United States coastal waters (see Table 1). It is worth noting that spirolides $\mathrm{E}$ and $\mathrm{F}$ were not detected in dinoflagellates, but were attributed to be metabolically modified products present in shellfish (Hu et al., 1996).

\section{Table 1 near here}

Table 1. Dinoflagellate species known to produce spirolides, their location and produced compounds.

\begin{tabular}{|c|c|c|}
\hline \multirow{15}{*}{ Alexandrium ostenfeldii } & Canada & $\begin{array}{l}\text { Spirolides A, B, C, C2, C3, D, D2, D3, H and I } \\
\text { 13-desmethyl Spirolides C and D }\end{array}$ \\
\hline & Norway & 20-methyl Spirolide G \\
\hline & \multirow{3}{*}{ Denmark } & Spirolides D and G \\
\hline & & 13-desmethyl Spirolides C and D \\
\hline & & 13,19-didesmethyl Spirolide C \\
\hline & \multirow{6}{*}{ Italy } & Spirolide D \\
\hline & & 13-desmethyl Spirolides C and D \\
\hline & & 13,19-didesmethyl Spirolide C \\
\hline & & 27-hydroxy-13,19-didesmethyl Spirolide C \\
\hline & & 27-oxo-13,19-didesmethyl Spirolide C \\
\hline & & 27-hydroxy-13-desmethyl Spirolide C \\
\hline & Scotland & Spirolide C \\
\hline & \multirow{3}{*}{ Ireland } & Spirolides C and D \\
\hline & & 13-desmethyl Spirolide C \\
\hline & & 20-methyl Spirolide G \\
\hline \multirow{5}{*}{ Alexandrium peruvianum } & \multirow{2}{*}{ Mediterranean Sea } & Spirolides B, C and D \\
\hline & & 13-desmethyl Spirolides C and D \\
\hline & Ireland & 13-desmethyl Spirolides C and D \\
\hline & \multirow{2}{*}{ Unired States } & Spirolide D \\
\hline & & 13-desmethyl Spirolides C and D \\
\hline
\end{tabular}

\section{- Pharmacokinetics/toxicokinetics of spirolide toxins}

Among the spirolides, both 13-desmethyl spirolide-C and 13,19-didesmethyl spirolide-C have been shown to cross a Caco-2 cell monolayer (Espiña et al., 2011). Caco-2 trans-epithelial permeability assays represent a good model to predict the intestinal absorption of drugs and toxins. When administered orally with a single non-lethal dose to mice deprived of food ( 24 hours before, but given a nutritive solution with salts and glucose) both spirolides were detected in blood and urine samples after 15 minutes and 1 hour of administration, respectively as revealed by liquid chromatography-tandem mass spectrometry (Otero et al., 2012). The 13-desmethyl spirolide-C and 13,19-didesmethyl spirolide-C were also detected 1 hour after intraperitoneal (i.p.) administration in urine, and trace amount of both toxins in blood; after 24 hours important amounts were detected in 
feces. These results indicate that spirolides are absorbed when administered orally, and are excreted through the urine and feces. The histological evaluation by light microscopy of the heart, kidneys, liver, spleen, stomach, and intestines, performed 24 hours and 7 days after oral administration, did not reveal any observable alteration (Otero et al., 2012). Further studies, using ultra-performance liquid chromatography-mass spectrometry and proton magnetic resonance spectroscopy, have shown that 13-desmethyl spirolide- $\mathrm{C}$ is found in the brain a few minutes after its intraperitoneal injection to 3xTg mouse (a well-known model of Alzheimer's disease), and remains measurable even 24 hours post-administration, indicating that the spirolide traverses the blood brain barrier. Furthermore, a decrease in the intracellular amyloid beta levels in the hippocampus of treated 3xTgmice was observed, emphasizing the positive effects of the molecule in this mouse model (Alonso et al., 2013).

\section{- Toxicity of spirolide toxins}

Although in vitro cytotoxicity tests have been used, the most appropriate assays for appraising the toxicity of Cyclic Imine toxins and estimating their risk to human health are in vivo methods. Hence, to date, most if not all studies regarding the acute toxicity of cyclic imines have been performed using mainly the mouse bioassays - with synthetic toxins, or toxins extracted from either cultured dinoflagellates or contaminated shellfish, administrated to animals by i.p. injection, gavage administration, or voluntary consumption (feeding) - and determining their $50 \%$ lethal dose $\left(\mathrm{LD}_{50}\right)$ values. It is worth noting that cyclic imine oral administration, with feeding taking priority over gavage, is a more relevant method since, first, it closely reproduces the situation in humans, and second, it avoids the use of high concentrations of solvent (i.e. ethanol) to dissolve the toxins (for reviews, see Molgó et al., 2014a; Stivala et al., 2015).

Spirolides, as the other cyclic imines, are classified as "fast-acting" toxins because they induced rapid onset of neurological symptoms - including hyperactivity, jumping, piloerection, hyperextension of the back, stiffening and arching of the tail toward the head, tremors progressing to spams, as well as skeletal muscle paralysis and extension of the hind limbs, respiratory distress with marked abdominal breathing, tremors of the whole body and severe dyspnea - followed by death due to respiratory arrest within 3-50 minutes, whatever the route of administration is. It is worth noting that animals that did not die usually fully recovered with no detectable long-term effects, confirming that the Cyclic Imine toxins are rapidly detoxified and/or excreted (see above). The $\mathrm{LD}_{50}$ of some spirolide congeners, after i.p. injection to mice, revealed that these compounds are the most toxic among cyclic imines toxins. In particular, spirolide- $\mathrm{C}$ as well as, although contested (Munday et al., 2012; Otero et al., 2012), 13-desmethyl spirolide-C and 20-methyl spirolide-G were the most toxic with $\mathrm{LD}_{50}$ values as low as $0.007-0.008 \mathrm{mg} / \mathrm{kg}$ mouse, followed by 
13,19-didesmethyl spirolide-C and spirolide-A (with $\mathrm{LD}_{50}$ of 0.032 and $0.037 \mathrm{mg} / \mathrm{kg}$ mouse, respectively). The other spirolide congeners exhibit an apparently much lower toxicity (Table 2). Interestingly, the comparison of the acute toxicity of spirolides and their chemical structure points out the importance of some structural requirements, such as the imine ring with the C31 methyl group, and the methyl group at C19, for the toxicological potency of the molecule. Although showing similar rank orders in the acute toxicity response, the $\mathrm{LD}_{50}$ of spirolide congeners after oral administration to mice via gavage are higher than those by i.p. injection, and even higher when administered by feeding (Table 2). The significant reduction in oral toxicity versus i.p. administration of pure spirolide congeners is consistent with the absence of harmful effects in humans consuming shellfish contaminated with these cyclic imine toxins, with the exception of non-specific symptoms, such as gastric distress and tachycardia, reported in Canada (Richard et al., 2001). However, the risk to human health of spirolide accumulation in shellfish is evidenced by the two following findings. First, the $\mathrm{LD}_{50}$ of lipophilic shellfish extracts, containing mainly 13desmethyl spirolide-C, was shown to be higher after i.p. than oral administration to mice (Richard et al., 2001), and second, examination of the brains of mice and rats after i.p. injection with this spirolide congener revealed neuronal damage in the hippocampus and brain stem, with increased mRNA levels of muscarinic and nicotinic acetylcholine receptors (Gill et al., 2003).

\section{Table 2 near here}

Table 2. The $50 \%$ lethal doses $\left(L_{50}\right)$ of spirolide congeners according to their administration route.

\begin{tabular}{|llcc|}
\hline Spirolide & Administration mode & LD $_{50}$ (mg/kg mouse) & Ratio (compared to i.p.) \\
\hline \multirow{2}{*}{ Spirolide A } & Intraperitoneal injection & 0.037 & 1 \\
\cline { 2 - 4 } & Gavage & $0.24-0.55$ & $6.5-14.9$ \\
\cline { 2 - 4 } & Feeding & $1.2-1.3$ & $32.4-35.1$ \\
\hline \multirow{2}{*}{ Spirolide B } & Intraperitoneal injection & 0.099 & 1 \\
\cline { 2 - 4 } & Gavage & 0.440 & 4.4 \\
\hline \multirow{3}{*}{ Spirolide C } & Intraperitoneal injection & 0.008 & 1 \\
\cline { 2 - 4 } & Gavage & $0.053-0.18$ & $6.6-22.5$ \\
\cline { 2 - 4 } & Feeding & $0.5-0.78$ & 1 \\
\hline \multirow{3}{*}{ 13-desmethyl Spirolide C } & Intraperitoneal injection & $0.007-0.028$ & $1.6-22.9$ \\
\cline { 2 - 4 } & Gavage & $0.13-0.16$ & $17.9-142.9$ \\
\cline { 2 - 4 } & Feeding & $0.5-1$ & 1 \\
\hline 13,19-didesmethyl Spirolide C & Intraperitoneal injection & 0.032 & 1 \\
\hline 27-hydroxy-13-desmethyl Spirolide C & Intraperitoneal injection & $>0.027$ & 1 \\
\hline 27-oxo-13,19-didesmethyl Spirolide C & Intraperitoneal injection & $>0.035$ & 1 \\
\hline Spirolide E & Intraperitoneal injection & $>1.000$ & 1 \\
\hline Spirolide F & Intraperitoneal injection & $>1.000$ & $<1.4$ \\
\hline \multirow{2}{*}{ 20-methyl Spirolide G } & Intraperitoneal injection & $0.008->0.063$ & $<7.9$ \\
\hline
\end{tabular}

\section{- Molecular targets and mechanism of action of spirolide toxins}

From the large number of compounds found in nature known to interact with nicotinic acetylcholine receptors (nAChRs), including a number of alkaloids and peptides from various origins, only a few 
are known to be produced by dinoflagellates. Dinoflagellate toxins known to interact with nAChRs include the spirolides, gymnodimines and pinnatoxins (for a recent review, see Stivala et al., 2015). The nAChRs are ligand-gated ion channels mediating fast neurotransmission in the central and peripheral nervous systems (reviewed in Corringer et al., 2000; Albuquerque et al., 2009). At the skeletal neuromuscular junction, the $\mathrm{nAChR}$ is a pentamer consisting of two $\alpha 1$-subunits, single $\beta 1$ and $\delta$-subunits, and either a $\gamma$ or a $\varepsilon$ subunit in the embryonic or adult receptor-type, respectively (Fig. 3). The neuronal nAChRs in the peripheral and central nervous systems are composed of pentameric combinations of $\alpha$ and $\beta$ subunits and exhibit a great heterogeneity in subtypes. To date, nine nAChR $\alpha$ subunits $(\alpha 2-\alpha 10)$ and three $\mathrm{nAChR} \beta$ subunits $(\beta 2-\beta 4)$ have been cloned from distinct animal species. In the peripheral nervous system, the primary subtype is the heteromeric $\alpha 3 \beta 4$ subtype, which is present in autonomic ganglia neurons. In addition, the $\alpha 3$ subunit may assemble with $\alpha 5$ and/ or $\beta 2$ subunit to form a variety of nAChRs. The other major subtype of neuronal $\mathrm{nAChR}$ in the peripheral and central nervous system comprised $\alpha 7$ subunits forming a homomeric $\mathrm{nAChR}$, as well as heteromers made up from the combination of different $\alpha$ subunits, or $\alpha$ and $\beta$ subunits. These arrangements include the $\alpha 4 \beta 2 \mathrm{nAChR}$, which is abundant and widely distributed in the central nervous system, and more complex subunit combinations with the presence of additional subunit types may exist. Thus, a major characteristic of neuronal nAChRs is their wide heterogeneity, based on both diverse stoichiometry and subunit composition.

Figure 3 near here

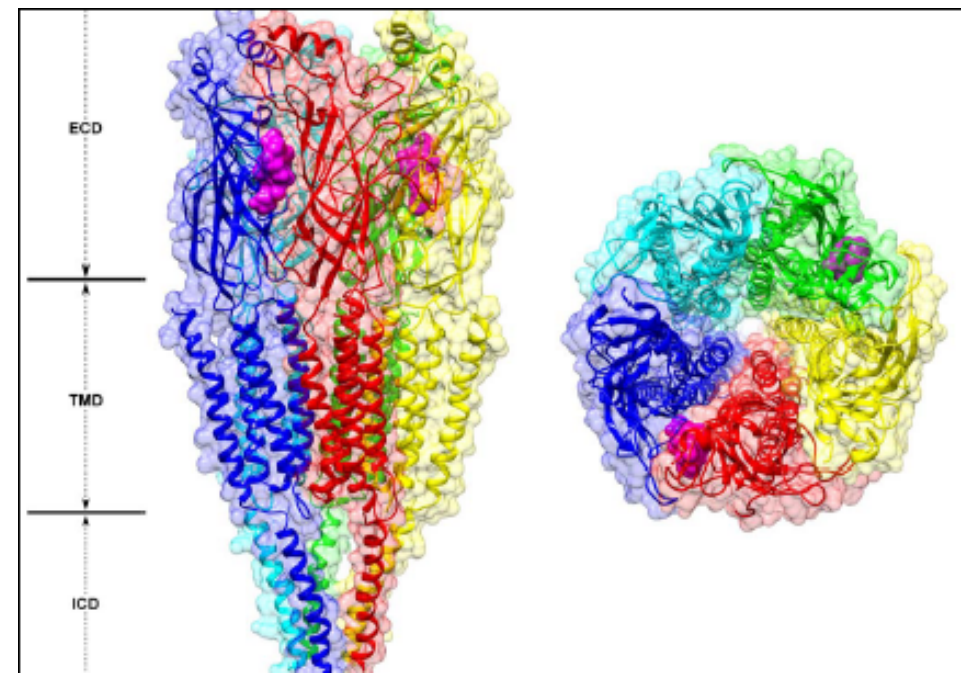

Figure 3. Three-dimensional structure of the muscle-type nAChR (Torpedo marmorata) obtained by cryoelectron microscopy (Protein Data Bank code 2BG9). The five subunits are colored in red, yellow, green, cyan and blue. The two antagonist sites where the spiroimine toxins can bind are shown as magenta-colored surfaces. Left: lateral view showing the extracellular (ECD), transmembrane (TMD) and intracellular (ICD) domains. Right: top view showing the organization of the five subunits arranged around the central pore.

Using both electrophysiological techniques and competition ligand-binding assays, it has been shown that 13-desmethyl spirolide-C and analogue spirolide compounds interact with muscle-type 
nAChRs existing at the neuromuscular junction of skeletal muscle, and with the major neuronal nAChRs present in the central and peripheral nervous system.

The functional characterization of the action of spirolides on nAChRs has been performed using the voltage-clamp technique and Xenopus oocytes that have incorporated into their membrane or express a given $\mathrm{nAChR}$ subtype. These studies revealed that neither 13-desmethyl spirolide-C nor 13,19-didesmethyl spirolide-C exhibit an agonist action on the muscle-type $\left(\alpha 1_{2} \beta 1 \gamma \delta\right) \mathrm{nAChR}$ incorporated to the oocyte membrane, or in oocytes expressing the human homomeric $\alpha 7$ and the human heteromeric $\alpha 4 \beta 2 \mathrm{nAChR}$. Acetylcholine (ACh), the endogenous agonist of nAChRs, is known to trigger conformational changes in the receptor which lead to the opening of the intrinsic cation channel, producing an inward current due to simultaneous entry of $\mathrm{Na}^{+}$and $\mathrm{Ca}^{2+}$ ions and the exit of $\mathrm{K}^{+}$ions that leads to membrane depolarization. Under voltage-clamp conditions an agonist effect is seen as an inward current relative to the baseline holding current that keeps the membrane potential constant. Thus, in contrast to $\mathrm{ACh}$, spirolides produced a concentration-dependent block of the ACh-evoked current in muscle-type $\left(\alpha 1_{2} \beta 1 \gamma \delta\right)$ and neuronal $\alpha 7$, and $\alpha 4 \beta 2 \mathrm{nAChR}$ subtypes (Aráoz et al., 2009; Bourne et al., 2010). The antagonist activity of 13-desmethyl spirolide-C is long-lasting, since it was not annihilated even after a 30 to $40 \mathrm{~min}$ of washout of the spirolide from the nAChR subtypes studied (Bourne et al., 2010).

Figure 4 near here

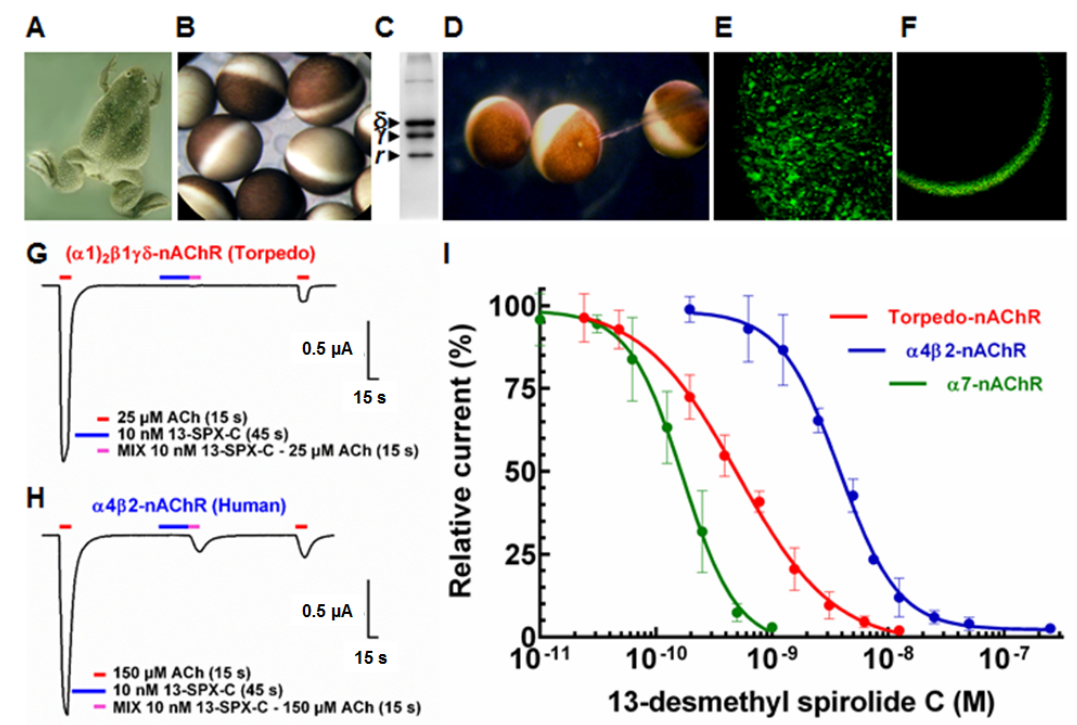

Figure 4. Experimental approaches used to study the action of spirolides and other spiroimine phycotoxins using electrophysiological techniques. (A) Mature female Xenopus laevis frog. (B) Oocytes at stages V to VI of development, surgically removed from an anesthetized mature female $X$. laevis under anesthesia. (C) Western blot of Torpedo marmorata purified membranes showing the $\mathrm{g}$ and $\mathrm{d}$ subunits of the nAChR and the rapsyn $(r)$ protein. (D) Manually defolliculated oocytes in which one is microinjected with $50 \mathrm{~nL}$ of purified Torpedo membranes using a Nanoliter 2010 Micro 4 Controller injector mounted on a microscope. (E, F) Staining of nAChRs incorporated to the membrane of an oocyte using fluorescent $\alpha$-Bungarotoxin, Alexa Fluor ${ }^{\circledR} 488$ conjugate. (G) Inward nicotinic current triggered by an ACh pulse of 15 seconds duration, recorded in an oocyte micro-injected 4 days previously with purified Torpedo membranes. Perfusion of 13-desmethyl spirolide C (13SPX-C) had no agonist action (blue tracing above recording), but complete blocked the ACh-evoked current 
when applied together with ACh (pink tracing). A further ACh pulse (red tracing above recording) only evoked a small current response consistent with low dissociation rate of the spirolide from the receptor. (H) ACh-evoked currents recorded in another oocyte expressing the human $\alpha 4 \beta 2 \mathrm{nAChR}$ before, and after the perfusion of the spirolide. Color tracing above recordings indicate protocols used. All recordings were performed at a holding potential of $-60 \mathrm{mV}$. The $\mathrm{ACh}$ concentration used corresponded to the $\mathrm{EC}_{50}$ determined for each $\mathrm{nAChR}$ subtype. (I) Inhibition of ACh-evoked currents recorded from Torpedo $\alpha 1_{2} \beta 1 \gamma \delta \mathrm{nAChR}$ incorporated into the oocyte membrane and human $\alpha 7$ and $\alpha 4 \beta 2$ nAChRs expressed in oocytes. The amplitudes of the ACh-evoked currents recorded in the presence of 13-desmethyl spirolide $\mathrm{C}$ (mean $\pm \mathrm{SEM}$; 3-4 oocytes per concentration) were normalized to control currents and fitted to the Hill's equation.

Competition binding studies performed on membranes from cells expressing different $\mathrm{nAChR}$ subtypes using the radiolabeled probes $\left[{ }^{125} \mathrm{I}\right] \alpha$-bungarotoxin, $\left[{ }^{3} \mathrm{H}\right]$ epibatidine or $\left[{ }^{3} \mathrm{H}\right]$ nicotine, and standard ligand-binding methods (reviewed in Molgó et al., 2013) allowed to get a better understanding into the interaction between spirolides and nAChRs. These competition-binding assays, performed at equilibrium, demonstrated that 13-desmethyl spirolide-C totally displaced $\left[{ }^{125} \mathrm{I}\right] \alpha$-bungarotoxin, in a concentration-dependent manner, not only from Torpedo membranes expressing the muscle-type nAChR, but also from HEK-293 cells expressing the chicken chimeric $\alpha 7-5 \mathrm{HT}_{3}$ neuronal $\mathrm{nAChR}$. This phycotoxin interacts also with high affinity and displaced $\left[{ }^{3} \mathrm{H}\right]$ epibatidine binding from heteropentameric human $\alpha 3 \beta 2$ and $\alpha 4 \beta 2$ neuronal nAChRs (Bourne et al., 2010). Similar results have been obtained with other subtypes of nAChRs in which the 13desmethyl spirolide $\mathrm{C}$-has been studied with a rank order for binding affinities (Ki) as follows: $\alpha 7>$ $\alpha 6 \beta 3 \beta 4 \alpha 5>>$ rat $\alpha 3 \beta 4, \alpha 1_{2} \beta 1 \gamma \delta>\alpha 4 \beta 4$, human $\alpha 3 \beta 4>$ human $\alpha 4 \beta 2>$ rat $\alpha 4 \beta 2$ (Hauser et al., 2012). These results indicate that spirolides are competitive antagonists with a broad specificity on neuronal nAChRs.

Important advances have been made in the molecular and structural characterization of nAChRs and in the understanding of the molecular pharmacological profile of spirolides. A major step in our understanding of the structural determinants of the interaction between 13-desmethyl spirolide-C and nAChRs was the publication of the X-ray crystal structure for this phycotoxin in complex with the Aplysia californica acetylcholine binding protein (AChBP) (Bourne et al., 2010). The AChBPs are water-soluble pentameric proteins, produced by glial cells in the nervous system of mollusks (freshwater snails Lymnaea stagnalis and Bulinus truncatus and the marine snail Aplysia californica). Their physiological role is to bind the neurally-released ACh participating in the modulation of cholinergic synaptic transmission, and represent structural and functional homologues of the amino-terminal extracellular ligand-binding domain of nAChRs (reviewed in Sixma and Smit, 2003). Virtually all conserved amino acid residues existing in the nAChR family are present in the AChBPs, including those that are important for the ligand binding to the agonists $\mathrm{ACh}$ and nicotine, as well as for the competitive antagonists such as $\alpha$-bungarotoxin and dtubocurarine, and therefore have similar pharmacological properties. The binding of 13-desmethyl spirolide-C to the Aplysia-AChBP displayed picomolar affinities governed by diffusion-limited 
association and slow-dissociation, accounting for the apparent irreversibility detected in electrophysiological experiments (see above). The crystal structure of the 13-desmethyl spirolide-C bound to Aplysia-AChBP at $2.51 \AA$ resolution showed the phycotoxin precisely imbedded within the nest of aromatic side chains contributed by loops $\mathrm{C}$ and $\mathrm{F}$ on opposing faces of the subunit interface, which in normal conditions provide accommodation to ACh. The structure of 13desmethyl spirolide-C, and other related phycotoxins, guarantees an ideal positioning of the central cyclic imine as a pivot point. In addition, the architectural restraints of the uncommon macrocyclic ring structures stabilize conformers with favorably positioned substituents conferring high surface complementarity and minimize the loss of entropy as phycotoxins bind to the Aplysia-AChBP (Bourne et al., 2010).

\section{GYMNODIMINES}

\section{- Chemical characteristics of gymnodimine toxins}

The gymnodimines present a 6-membered cyclic imine, bearing no methyl substituents, as part of the spiroimine ring system, an unsaturated lactone and a tetrahydrofuran ring (Fig. 5). Two groups can be distinguished according to the substitution pattern at the positions $\mathrm{C} 17$ and $\mathrm{C} 18$. The first gymnodimine group has a methyl substituent at $\mathrm{C} 17$ and an $E$-configured endocyclic double bond between $\mathrm{C} 17$ and C18. Gymnodimine-A and its 12-methyl derivative are part of this group. The second gymnodimine group contains gymnodimines $\mathrm{B}$ and $\mathrm{C}$, which have an exocyclic double bond at $\mathrm{C} 17$ and a hydroxyl substituent at $\mathrm{C} 18$ with $S$ and $R$ stereochemistry, respectively.

\section{Figure 5 near here}
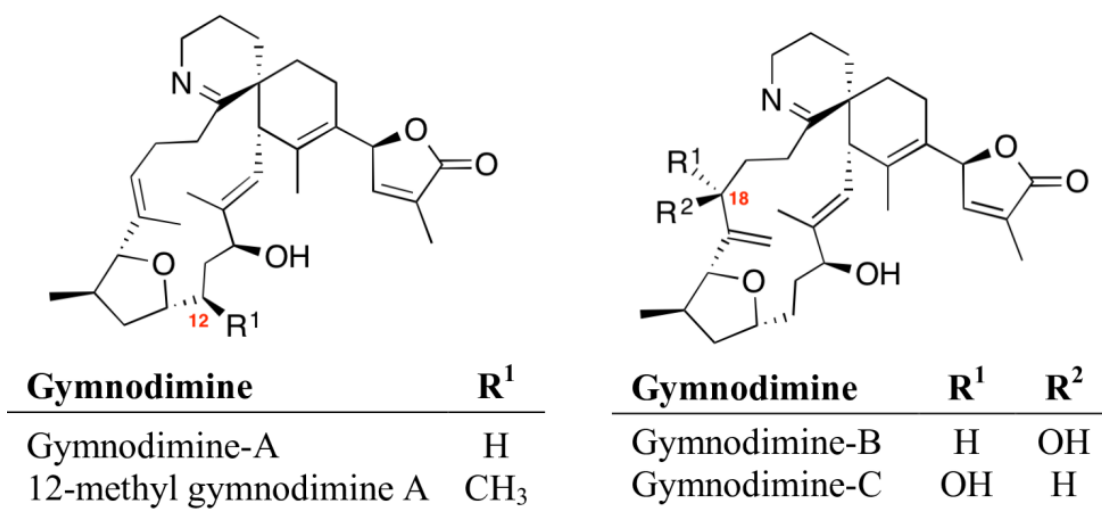

\begin{tabular}{lcc} 
Gymnodimine & $\mathbf{R}^{\mathbf{1}}$ & $\mathbf{R}^{\mathbf{2}}$ \\
\hline Gymnodimine-B & $\mathrm{H}$ & $\mathrm{OH}$ \\
Gymnodimine-C & $\mathrm{OH}$ & $\mathrm{H}$
\end{tabular}

Figure 5. Chemical structures of the known gymnodimine toxins.

\section{- Gymnodimine producing organisms}

The production of the gymodimines identified so far (gymnodimes-A, -B and -C) was exclusively attributed to the dinoflagellate Karenia selliformis (Haywood et al., 2004) (formely known as 
Gymnodinium selliforme) in New Zealand and Australia (Table 3). However, the gymnodimine congener 12-methyl gymnodimine was reported as originating from another dinoflagellate in the United States, Alexandrium peruvianum (Van Wagoner et al., 2011) (Table 3), which was proven to also produce some spirolide congeners (see Table 1).

\section{Table 3 near here}

Table 3. Dinoflagellate species known to produce gymnodimine congeners.

\begin{tabular}{|lll|}
\hline \multirow{2}{*}{ Karenia selliformis } & New Zealand & Gymnodimines A, B and C \\
\cline { 2 - 3 } & Australia & Gymnodimine A \\
\hline Alexandrium peruvianum & Unired States & 12-methyl Gymnodimine \\
\hline
\end{tabular}

\section{- Toxicity of gymnodimine toxins}

The gymnodimines are among the least toxic cyclic imines according to the mouse bioassay irrespective of the route of administration is (i.p. injection, gavage or feeding administration). Their acute oral toxicity, in particular that of gymnodimine-A, was shown to be between about 8- and more than 78-fold lower than the i.p. toxicity (Munday et al., 2004) (Table 4). It is worth noting that gymnodimine-A was reported to be about 10-fold more toxic than gymnodimine-B after i.p. injection to animals. Remarkably, the $\mathrm{LD}_{50}$ for gymnodimine-A was decreased by about 30 -fold when administered to mice by intracerebroventricular administration, as compared to i.p. injection (i.e. 0.003 and 0.08-0.096 mg/kg mouse, respectively (Kharrat et al., 2008) (Table 4). This indicates that gymnodimine-A preferentially affected the rodent central nervous system, further highlighting the risk of the Cyclic Imine toxins to human health may have when accumulated in shellfish at high concentrations.

\section{Table 4 near here}

Table 4. The $50 \%$ lethal doses $\left(L_{50}\right)$ of gymnodimine congeners according to their administration route.

\begin{tabular}{|llcc|}
\hline Gymnodimine & Administration mode & $\mathbf{L D}_{\mathbf{5 0}}$ ( $\mathbf{m g} / \mathbf{k g}$ mouse) & Ratio (compared to i.p.) \\
\hline Gymnodimine A & Intraperitoneal injection & $0.08-0.096$ & 1 \\
\cline { 2 - 4 } & Intracerebroventricular injection & 0.003 & $0.03-0.038$ \\
\cline { 2 - 4 } & Gavage & 0.755 & $7.9-9.4$ \\
\cline { 2 - 4 } & Feeding & $4.057->7.5$ & $42.3->78.1$ \\
\hline Gymnodimine B & Intraperitoneal injection & 0.800 & 1 \\
\hline
\end{tabular}

\section{- Molecular targets and mechanism of action of gymnodimine toxins}

Gymnodimine-A at nanomolar concentrations was reported to produce a concentration-dependent block of twitch tension responses evoked by nerve stimulation in isolated mouse phrenic-nerve hemidiaphragm-muscle preparations, without affecting muscle excitability and directly elicited muscle contraction. Also, gymnodimine-A, according to the nanomolar concentration used, either reduced the amplitude or completely blocked miniature-endplate potentials generated by the release of a single ACh quantum (Kharrat et al., 2008). Similarly, gymnodimine-A blocked the amplitude 
of endplate potentials without affecting the resting membrane potential of muscle fibers. Such an action prevented endplate potentials to reach the threshold potential for action potential generation in muscles fibers, strongly suggesting that gymnodimine-A blocked endplate nAChRs. Direct evidence for such an action was obtained, using both the patch-clamp technique and iontophoretic ACh pulses of constant duration delivered by a micropipette on the surface of Xenopus skeletal myocytes expressing the embryonic muscle-type nAChR in their surface (Kharrat et al., 2008). Gymnodimine-A was shown both to have no agonist action on such receptors, but to block reversibly the inward nicotinic currents elicited by the iontophoretic ACh pulses. Furthermore, the inhibition of ACh-activated currents by gymnodimine-A was clearly independent of the holding membrane potential, in other terms had no voltage-dependence. Interestingly, the neuromuscular block produced by gymnodimine-A could be reversed by continuous washout of the phycotoxin from the medium within $30 \mathrm{~min}$. Also, the block of $\mathrm{K}^{+}$channels in motor nerve terminals by 3,4diaminopyridine $(100 \mu \mathrm{M})$, which increases evoked quantal ACh release by nerve impulses (Van der Kloot and Molgó, 1994), was able to antagonize the action of the phycotoxin. In addition, gymnodimine-A, in a reversible manner, blocked ACh-evoked currents in Xenopus oocytes expressing heterologous human $\alpha 7 \mathrm{nAChRs}$, and this block was independent of the holding membrane potential (Kharrat et al., 2008).

Further insight into the interaction between gymnodimine-A and the muscle-type $\alpha 1_{2} \beta 1 \gamma \delta \mathrm{nAChR}$ was gained in competition binding studies using $\left[{ }^{125} \mathrm{I}\right] \alpha$-bungarotoxin as a tracer and HEK-293 cells expressing this nAChR. Gymnodimine-A totally displaced, in a concentration-dependent manner, $\left[{ }^{125} \mathrm{I}\right] \alpha$-bungarotoxin from HEK-293 cells expressing the muscle-type $\alpha 1_{2} \beta 1 \gamma \delta \mathrm{nAChR}$ or the chimeric neuronal $\alpha 7-5-\mathrm{HT} 3 \mathrm{nAChR}$. Furthermore, gymnodimine-A inhibited the specific $\left[{ }^{3} \mathrm{H}\right]$ epibatidine binding on HEK293 cells expressing either $\alpha 4 \beta 2$ or $\alpha 3 \beta 2$ neuronal nAChRs. These data are consistent with the fact that gymnodimine-A was highly toxic when applied directly into the mouse central nervous system by intracerebroventricular injection. The rank order of potency for gymnodimine-A on the various nAChRs studied was: $\alpha 7-5 \mathrm{HT} 3>\alpha 1_{2} \beta 1 \gamma \delta>\alpha 3 \beta 2>$ $\alpha 4 \beta 2$ (Kharrat et al., 2008). In another study the rank order for binding affinity (Ki) was $\alpha 7$, $\alpha 6 \beta 3 \beta 4 \alpha 5>$ rat $\alpha 3 \beta 4>$ human $\alpha 3 \beta 4, \alpha 4 \beta 4>$ rat $\alpha 4 \beta 2$, human $\alpha 4 \beta 2$ (Hauser et al., 2012).

Some 6,6-spiroimine analogs of gymnodimine-A have been chemically synthesized, and were shown to block ACh-evoked nicotinic currents in Xenopus oocytes having incorporated the Torpedo muscle-type $\left(\alpha 1_{2} \beta 1 \gamma \delta\right) \mathrm{nAChR}$ in their membrane, or expressing the human $\alpha 4 \beta 2 \mathrm{nAChR}$ (Duroure et al., 2011). Although these spiroimine analogs are about 40-45 times less active than gymnodimine-A, the fact that they block both types of nAChRs indicate that the 6,6-spiroimine moiety is a key structural factor required for blocking nAChRs in the gymnodimine family. 
The X-ray crystal structure of gymnodimine-A in complex with Aplysia-AChBP has been determined (Bourne et al., 2010). The structures obtained indicate that gymnodimine-A was bound at the subunit interface, between loops $\mathrm{C}$ and $\mathrm{F}$ from opposing faces, in the same region where $\mathrm{ACh}$ binds. In addition, the structures highlighted the characteristic hydrogen bond between the iminium nitrogen in gymnodimine-A and the carbonyl oxygen of Trp 147 from loop C, and also the anchoring interactions of the tetrahydrofuran component in gymnodimine-A with the apical and membrane extremities of the binding site, along the subunit interface.

\section{PINNATOXINS, PTERIATOXINS AND PORTIMINE}

\section{- Chemical characteristics of pinnatoxins and pteriatoxins}

To date, eight pinnatoxins $(\mathrm{A}-\mathrm{H})$ and three pteriatoxins $(\mathrm{A}-\mathrm{C})$ have been described. They all share the same common scaffold with a dimethyl substituted 7-membered cyclic imine as part of a spiroimine ring system, a 6,5,6-spiroketal ring system and a bridged ketal which is unique within the cyclic imine phycotoxins family (Fig. 6). The pinnatoxins and pteriatoxins are differentiated by the substituent at C33, which might be carboxyl (pinnatoxin-A), vinyl (pinnatoxins $\mathrm{G}$ and $\mathrm{H}$ ), glycinyl (pinnatoxins $\mathrm{B}$ and $\mathrm{C}$ ), butyrolactone (pinnatoxin-F) or hydroxy/keto-butyric acid (pinnatoxins D and E), as well as $S$-cysteinyl derivatives (pteriatoxins A-C). Other positions with substituent variability are 21,22 and 28 , for which we observe two substitution patterns: $\mathrm{H}, \mathrm{H}$ and $\mathrm{OH}$ (pinnatoxins $\mathrm{A}, \mathrm{B}, \mathrm{C}, \mathrm{G}$ and pteriatoxins $\mathrm{A}, \mathrm{B}, \mathrm{C}$ ), and $\mathrm{CH}_{3}, \mathrm{OH}$ and $\mathrm{H}$ (pinnatoxins $\mathrm{D}, \mathrm{E}, \mathrm{F}$, $\mathrm{H})$, respectively.

Figure 6 near here 


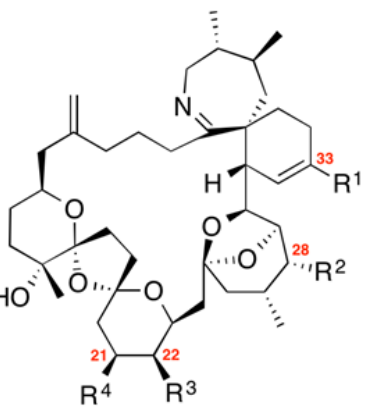

\begin{tabular}{|c|c|c|c|c|}
\hline Pinnatoxin / Pteriatoxin & $\mathbf{R}^{1}$ & $\mathbf{R}^{2}$ & $\mathbf{R}^{3}$ & $\mathbf{R}^{4}$ \\
\hline Pinnatoxin-A & $\mathrm{CO}_{2}$ & $\mathrm{OH}$ & $\mathrm{H}$ & $\mathrm{H}$ \\
\hline Pinnatoxin-B & & $\mathrm{OH}$ & $\mathrm{H}$ & $\mathrm{H}$ \\
\hline Pinnatoxin- $\mathrm{C}$ & & $\mathrm{OH}$ & $\mathrm{H}$ & $\mathrm{H}$ \\
\hline Pinnatoxin-D & & $\mathrm{H}$ & $\mathrm{OH}$ & $\mathrm{CH}_{3}$ \\
\hline Pinnatoxin-E & & $\mathrm{H}$ & $\mathrm{OH}$ & $\mathrm{CH}_{3}$ \\
\hline Pinnatoxin-F & & $\mathrm{H}$ & $\mathrm{OH}$ & $\mathrm{CH}_{3}$ \\
\hline Pinnatoxin-G & & $\mathrm{OH}$ & $\mathrm{H}$ & $\mathrm{H}$ \\
\hline Pinnatoxin-H & & $\mathrm{H}$ & $\mathrm{OH}$ & $\mathrm{CH}_{3}$ \\
\hline Pteriatoxin-A & & $\mathrm{OH}$ & $\mathrm{H}$ & $\mathrm{H}$ \\
\hline Pteriatoxin-B & & $\mathrm{OH}$ & $\mathrm{H}$ & $\mathrm{H}$ \\
\hline Pteriatoxin-C & & $\mathrm{OH}$ & $\mathrm{H}$ & $\mathrm{H}$ \\
\hline
\end{tabular}

Figure 6. Chemical structures of the known pinnatoxins and pteriatoxins.

\section{- Pinnatoxin and pteriatoxin producing organisms}

Identical strains of dinoflagellates were shown to be responsible for the production of pinnatoxins $\mathrm{E}$ and $\mathrm{F}$ in New Zealand, pinnatoxins A, E, F and/or G in South Australia, and pinnatoxin-G in Japan (Rhodes et al., 2011). The recognition of the dinoflagellate producer of pinnatoxins was ultimately associated with the discovery of a new dinoflagellate species, named Vulcanodinium rugosum (Nézan and Chromérat, 2011) in water samples of a Mediterranean lagoon in the French coast, which produced pinnatoxin-G (Table 5). Recently, a new pinnatoxin analog, pinnatoxin-H, was purified from a culture of the dinoflagellate Vulcanodinium rugosum from the South China Sea (Selwood et al., 2014). It is worth noting that the fatty acid esters of pinnatoxins A and G isolated from Canadian mussels were reported to likely originate from the shellfish than from the dinoflagellate (McCarron et al., 2012). Similarly, there is no conclusive evidence for the 
dinoflagellate source of pteriatoxins, isolated from the Japanese bivalve Pteria penguin (Shumway, 1990).

\section{Table 5 near here}

Table 5. Dinoflagellate species known to produce pinnatoxin congeners.

\begin{tabular}{|lll|}
\hline Vulcanodinium rugosum & Australia & Pinnatoxins A, E, F and G \\
\cline { 2 - 3 } & New Zealand & Pinnatoxins E and F \\
\cline { 2 - 3 } & Japan & Pinnatoxin G \\
\cline { 2 - 3 } & France & Pinnatoxin G \\
\cline { 2 - 3 } & China & Pinnatoxin $\mathrm{H}$ \\
\hline
\end{tabular}

\section{- Toxicity of pinnatoxins and pteriatoxins}

Acute toxicological studies with purified samples of pinnatoxin congeners, administered by i.p. injection, revealed that pinnatoxin $\mathrm{F}$ was between about 2.7 and 5.1 times more potent than pinnatoxins $\mathrm{E}, \mathrm{G}$ and $\mathrm{H}$ (Table 6), showing the following rank order of potency in the acute toxicity response: pinnatoxin $\mathrm{F}>$ pinnatoxin $\mathrm{G}>$ pinnatoxin $\mathrm{E}>$ pinnatoxin $\mathrm{H}$ (Munday et al., 2012b). $\mathrm{A}$ different rank order in the acute toxicity response (i.e. pinnatoxin $F>$ pinnatoxin $G>$ pinnatoxin $H$ $>$ pinnatoxin E) was obtained for gavage administration. The oral toxicity of pinnatoxin-F was only between 5- and 6.5-fold higher than that of pinnatoxins $\mathrm{G}$ and $\mathrm{H}$, but was about 93.3-fold higher than that of pinnatoxin E. As detailed previously for spirolide congeners and gymnodime-A, the oral toxicity of pinnatoxin-E was at least 49 -fold lower than the i.p. toxicity, while comparatively smaller differences were observed for pinnatoxins $F, G$ and $H$ between the two routes of administration (Table 6). These findings are of great interest regarding the risk these toxins may have to human health. Only a few reports were concerned with the acute toxicity of pteriatoxins, but they revealed that these toxins produce animal lethality at doses between 0.008 and $0.1 \mathrm{mg} / \mathrm{kg}$ when administrated to mouse by i.p. injection, with toxic symptoms resembling those of pinnatoxins (see Takada et al., 2001). The atypically stability of the aliphatic cyclic imine in pinnatoxins (Jackson et al., 2012) is probably associated to their high oral toxicity, highest among the Cyclic Imine toxins.

\section{Table 6 near here}

Table 6. The $50 \%$ lethal doses $\left(\mathrm{LD}_{50}\right)$ of pinnatoxin congeners according to their administration route.

\begin{tabular}{|llcc|}
\hline Pinnatoxin & Administration mode & $\mathbf{L D}_{50}(\mathbf{m g} / \mathbf{k g}$ mouse) & Ratio (compared to i.p.) \\
\hline \multirow{2}{*}{ Pinnatoxin E } & Intraperitoneal injection & $0.045-0.057$ & 1 \\
\cline { 2 - 4 } & Gavage & 2.800 & $49.1-62.2$ \\
\hline \multirow{2}{*}{ Pinnatoxin F } & Intraperitoneal injection & $0.013-0.016$ & 1 \\
\cline { 2 - 4 } & Gavage & $0.025-0.03$ & $1.6-2.3$ \\
\cline { 2 - 4 } & Feeding & $0.05-0.077$ & $3.1-5.9$ \\
\hline \multirow{2}{*}{ Pinnatoxin G } & Intraperitoneal injection & $0.043-0.05$ & 1 \\
\cline { 2 - 4 } & Gavage & 0.150 & $3-3.5$ \\
\hline \multirow{2}{*}{ Pinnatoxin H } & Feeding & 0.400 & 1 \\
\hline & Intraperitoneal injection & 0.067 & 2.4 \\
\cline { 2 - 4 } & Gavage & 0.163 & \\
\hline
\end{tabular}




\section{- Molecular targets and mechanism of action of pinnatoxins and pteriatoxins}

The use of successful strategies for the chemical synthesis of pinnatoxins A and G (Beaumont et al., 2010; Stivala et al., 2015) allowed the production of substantial amounts of these toxins in pure form which permitted performing electrophysiological and functional studies, as well as competition binding studies together with computational molecular modeling, leading to the revision of the mode of action previously proposed for pinnatoxins. Thus, based on such analyses it has been unequivocally established that pinnatoxins $A$ and $G$ are potent antagonists of nAChRs (Aráoz et al., 2011). The rank order of potency for pinnatoxin-A on nAChR subtypes determined by functional analyses was the following: human $\alpha 7>$ Torpedo $\alpha 1_{2} \beta 1 \gamma \delta>$ human $\alpha 4 \beta 2$. The reversibility of the pinnatoxin-A activity was faster for the $\alpha 4 \beta 2 \mathrm{nAChR}$, while it was slowly reversible for the $\alpha 7 \mathrm{nAChR}$ subtype. Interestingly, pinnatoxin-A exhibited higher affinity than pinnatoxin-G for the human neuronal $\alpha 7 \mathrm{nAChR}$ subtype. In contrast, a synthetic aminoketone derivative of pinnatoxin-A with an open imine ring showed no activity on the various nAChR subtypes studied, a feature supporting the central role of the seven-membered cyclic imine ring for the potent antagonism of this family of toxins (Aráoz et al., 2011).

Also, pinnatoxins $\mathrm{E}, \mathrm{F}$ and $\mathrm{G}$ were reported to produce concentration-dependent reductions in nerve-evoked twitch tension in isolated rat hemidiaphragm preparations, with a rank order of potency of $\mathrm{F}>\mathrm{G}>\mathrm{E}$, while no effects were detected on directly muscle-evoked twitch responses. Pinnatoxins $\mathrm{F}$ and $\mathrm{G}$ moreover reduced the amplitude of spontaneous miniature endplate potentials and evoked endplate potentials at skeletal neuromuscular junctions, without affecting miniature endplate potential frequency or the resting membrane potential of the muscle fibers. These results show that pinnatoxins E, F and G are potent neuromuscular blockers and cause toxicity by acting as antagonists at muscle-type nicotinic acetylcholine receptors (Hellyer et al., 2013).

Further ligand-binding studies were performed to examine whether pinnatoxin-A had any action on other neurotransmitter receptors, including those coupled to G-proteins, and neurotransmitter transporters. However, no significant action, or very little action, was detected using a high concentration of pinnatoxin-A $(10 \mu \mathrm{M})$ on the different receptors studied including: adrenergic receptors (Alpha1A, Alpha1B, Alpha1D, Alpha2A, Alpha2B, Alpha2C, Beta1, Beta2, Beta3); muscarinic receptors (M1, M2, M3, M4 and M5); serotoninergic receptors (5-HT1A, 5-HT1B, 5HT1D, 5-HT1E, 5-HT2A, 5-HT2B, 5-HT2C, 5-HT3, 5-HT5A, 5-HT6, 5-HT7); GABAA receptor, dopaminergic receptors (D1, D2, D3, D4 and D5), Histamine receptors (H1 and H2), $\delta$-Opioid (DOR), $\kappa-$-Opioid (KOR), $\mu$-Opioid (MOR) and the dopamine transporter (DAT), norepinephrine transporter (NET) and serotonin transporter (SERT). Furthermore, no activity on Cav1.1 calcium channels (type-L) originally proposed to be the target of pinnatoxins, was observed (Aráoz et al., 
2011). These experimental results reveal an extraordinary selectivity of pinnatoxin-A for the nAChRs.

The evidence that spirolides, gymnodimines and pinnatoxins target nAChRs prompted the development of target-directed functional method, based on the mechanism of action of competitive antagonists on nAChRs. Thus, several non-radioactive ligand-binding methods have been developed (Vilariño et al., 2009; Fonfría et al., 2010; Otero et al., 2011; Aráoz et al., 2012; Rodriguez et al., 2013) to replace the traditional mouse bioassay which has numerous drawbacks related to sensitivity and specificity, apart from the ethical concern of using large number of animals, as recently discussed (Daneshian et al., 2013).

\section{- Portimine}

A new Cyclic Imine toxin, named portimine, has been recently discovered from the pinnatoxin producing dinoflagellate Vulcanodinium rugosus from Northland (New Zealand) (Selwood et al., 2013). The structure of portimine, including the relative configurations, was elucidated by spectroscopic analyses. The cyclic imine moiety consists of an unprecedented five-membered ring with a spiro-link to a cyclohexene ring (see Fig. 1). Portimine contains only 14 carbons in its macrocycle, making it the smallest Cyclic Imine toxin isolate to date. Such structural factors have a large impact on the toxin toxicity, since it has a much lower toxicity in rodent bioassays after i.p. administration $\left(\mathrm{LD}_{50}=1.57 \mathrm{mg} / \mathrm{kg}\right.$ mouse) than any other Cyclic Imine toxin. In contrast, portimine exhibits high toxicity in vitro to mammalian cells, with an $\mathrm{LC}_{50}$ of $2.7 \mathrm{nM}$ to mouse leukemia $\mathrm{P} 388$ cells, and activation of caspases indicates that it has apoptotic activity.

\section{PROROCENTROLIDES AND SPIRO-PROROCENTRIMINE}

\section{- Chemical characteristics of prorocentrolide and spiro-prorocentrimine toxins}

Prorocentrolides are the only members of the cyclic imine phycotoxins family that do not contain a spiroimine group. Their chemical structure includes a 26-membered carbo-macrocycle and a 28membered macrocyclic lactone arranged around a 3,4,4a,5,8,8a-hexahydroisoquinoline that incorporates the characteristic cyclic imine group. Six prorocentrolides have been reported to date (Fig. 7), which differ by the substituents at the positions 4 (hydrogen, hydroxy or sulfonate), 9 (methyl or exocyclic vinyl), 14 (hydroxy or acetate ester), 29 (methyl or hydrogen) and 30 (hydroxy or sulfonate). Prorocentrolide-B shows specific structural modifications at the positions 10 (exocyclic vinyl), 15 (hydrogen instead of hydroxy), 16 (hydroxy instead of hydrogen) and 29 (unsubstituted endocyclic $E$ double bond). 
A single spiro-prorocentrimine compound is currently known (see Fig. 1), whose chemical structure contains a 25-membered carbo-macrocycle and a 15-membered macrocyclic lactone arranged around a 6,6-spiroimine ring system. The overall structure and the stereochemistry of substituents have been unambiguously determined by X-ray crystallography (Lu et al., 2001).

\section{Figure 7 near here}

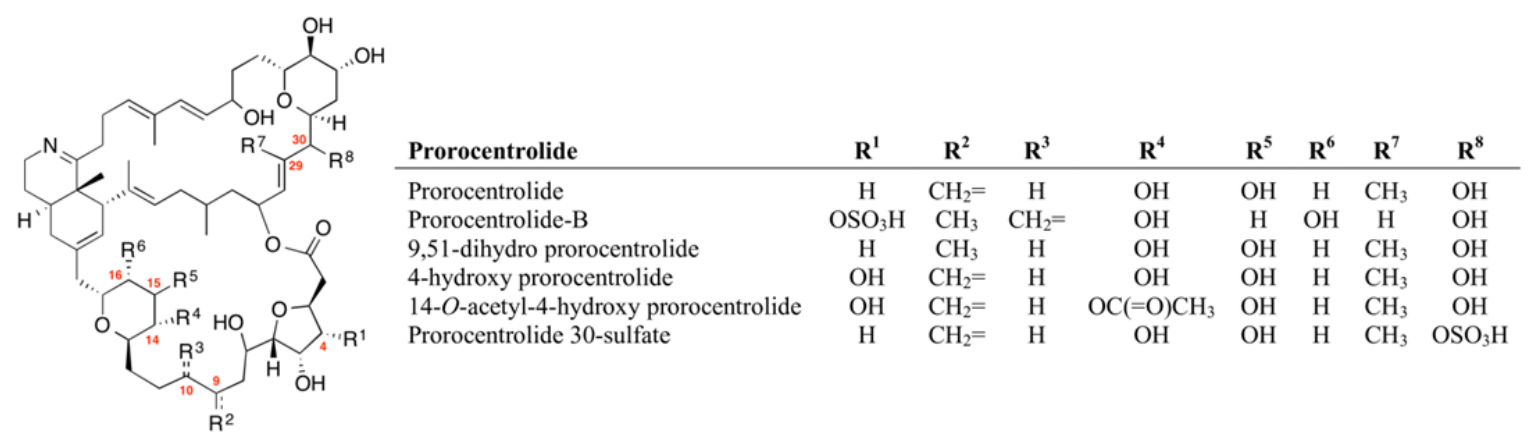

Figure 7. Chemical structures of the known prorocentrolide toxins.

\section{- Prorocentrolide and spiro-prorocentrimine producing organisms}

To date, the production of prorocentrolide congeners and spiro-prorocentrimine is well-known to be restricted to primarily benthic or epiphytic Prorocentrum sp. which, unlike their pelagic counterparts, does not form dense blooms. Hence, prorocentrolide A was isolated from Prorocentrum lima in Japan and Taiwan, and the structurally related cyclic imine prorocentolide B from Prorocentrum maculosum in tropical waters. The Taiwanese Prorocentrum lima also produces two prorocentrolide analogs, 4-hydroxy and 14-O-acetyl-4-hydroxy prorocentrolides. Finally, spiroprorocentrimine was isolated along with prorocentrolide A from another Taiwanese, still unidentified, strain of Prorocentrum sp. (Table 7).

\section{Table 7 near here}

Table 7. Dinoflagellate species known to produce prorocentrolide congeners and spiroprorocentrimine.

\begin{tabular}{|lll|}
\hline & Japan & Prorocentrolide A \\
\cline { 2 - 3 } Prorocentrum lima & Taiwan & $\begin{array}{l}\text { Prorocentrolide A } \\
\text { 4-hydroxy Prorocentrolide } \\
\end{array}$ \\
& & 14-O-acetyl-4-hydroxy Prorocentrolide \\
\hline Prorocentrum maculosum & Tropical waters & Prorocentrolide B \\
\hline \multirow{2}{*}{ Prorocentrum sp. } & Taiwan & $\begin{array}{l}\text { Prorocentrolide A } \\
\text { Spiro-prorocentrimine }\end{array}$ \\
\hline
\end{tabular}

\section{- Toxicity of prorocentrolide and spiro-prorocentrimine toxins}

Although only a few reports were concerned with the acute toxicity of prorocentrolide and spiroprorocentrimine toxins, they revealed that, when administrated to mouse by i.p. injection, prorocentrolide A had an animal lethality of $0.4 \mathrm{mg} / \mathrm{kg}$ mouse (Torigoe et al., 1988), while spiro- 
prorocentrimine exhibited much less toxicity (i.e. animal lethality occurred at $2.5 \mathrm{mg} / \mathrm{kg}$ mouse) than other known marine Cyclic Imine toxins (Lu et al., 2001).

\section{- Molecular targets and mechanism of action of prorocentrolide and spiro-prorocentrimine toxins}

The molecular targets for these Cyclic Imine toxins have not yet been determined, because of the lack of purified or synthetic toxins.

\section{CONCLUSION}

In conclusion, this short review shows that the well-chemically characterized natural products derived from some toxic dinoflagellates species constitute a novel source of potent nAChR-ligands molecules. The distinguishing feature of these phycotoxins is the presence of a cyclic imine moiety in their structure, which constitutes a chemical signature associated with their capacity to interact with muscle-types and neuronal-nAChR subtypes. Thus, spirolides, gymnodimines and pinnatoxins, which are recognized "fast-acting toxins", are known to broadly target muscle- and neuronal-type nAChRs, generally with high affinity for the various receptor subtypes studied. The sites of interaction of these toxins on nAChRs include amino acid residues highly conserved in the sequences of muscle- and neuronal-type receptors. Another important aspect in the action of these phycotoxins is the lack of animal species-selectivity, since similar actions have been reported on frog, fish, chick, rodent, and human nAChRs. The toxicological profile reported for these phycotoxins, during rodent bioassays, is mostly due to their specific interaction with the nAChRs.

The competitive binding to nAChRs has been exploited to design and develop new tests to detect spirolides, gymnodimines and pinnatoxins in contaminated shellfish with better accuracy than the broad spectrum mouse bioassay. These tests are important in the food safety field, since shellfish constitutes a worldwide rich food resource that may be contaminated by toxins produced by harmful dinoflagellates. Additional appropriate toxicological studies must be developed to assess the risk these phycotoxins may have to human health, since at present there is no strong evidence linking the presence of spirolides, gymnodimines and pinnatoxins in shellfish tissues with human intoxications. Also, more data is needed on the risks of chronic exposure to these phycotoxins. Shellfish frequently contains varying amounts of these toxins, at low or high concentrations, which is a risk factor for human health that cannot be neglected. Furthermore, shellfish concentrate these toxins in their edible tissues, and can act as vector for transferring these phycotoxins through the marine food web, thus menacing wildlife. 


\section{Acknowledgements}

Work performed in the laboratory of authors was funded by the "Agence Nationale de la Recherche" (France, grant AQUANEUROTOX ANR-12-ASTR-0037-1), and by the National Institutes of Health (USA, grant NIGMS R01 GM077379 to A.Z).

\section{REFERENCES}

1. Alonso E, Otero P, Vale C, Alfonso A, Antelo A, Giménez-Llort L, Chabaud L, Guillou C, Botana LM. Benefit of 13-desmethyl spirolide $C$ treatment in triple transgenic mouse model of Alzheimer disease: beta-amyloid and neuronal markers improvement. Curr. Alzheimer Res. 2013; 10:279-289.

2. Albuquerque EX, Pereira EF, Alkondon M, Rogers SW. Mammalian nicotinic acetylcholine receptors: From structure to function. Physiol. Rev. 2009; 89:73-120.

3. Aráoz R, Servent D, Molgó J, Iorga BI, Fruchart-Gaillard C, Benoit E, Gu Z, Stivala C, Zakarian A. Total synthesis of pinnatoxins $A$ and $G$ and revision of the mode of action of pinnatoxin A. J. Am. Chem. Soc. 2011; 133:10499-10511.

4. Aráoz R, Ramos S, Pelissier F, Guérineau V, Benoit E, Vilariño N, Botana LM, Zakarian A, Molgó J. Coupling the Torpedo microplate-receptor binding assay with mass spectrometry to detect cyclic imine neurotoxins. Anal. Chem. 2012. 84:10445-10453.

5. Aráoz R, Servent D, Ouanounou G, Benoit E, Molgó, J. The emergent marine dinoflagellate toxins spirolides and gymnodimines target nicotinic acetylcholine receptors. Biol. Res. 2009; 42 (Suppl. A): R-118.

6. Beaumont S, Ilardi EA, Tappin ND, Zakarian A. Marine Toxins with Spiroimine Rings: Total Synthesis of Pinnatoxin A. European J. Org. Chem. 2010; 2010(30):5743-5765.

7. Bourne Y, Radic Z, Aráoz R, Talle, TT, Benoit E, Servent D, Taylor P, Molgó J, Marchot P. Structural determinants in phycotoxins and AChBP conferring high affinity binding and nicotinic AChR antagonism. Proc. Natl. Acad. Sci. USA 2010; 107:6076-6081.

8. Cembella AD, Lewis NI, Quilliam MA. Spirolide composition of micro-extracted pooled cells isolated from natural plankton assemblages and from cultures of the dinoflagellate Alexandrium ostenfeldii. Nat. Toxins 1999; 7:197-206.

9. Christian B, Below A, Dressler N, Scheibner O, Luckas B, Gerdts G. Are spirolides converted in biological systems?-A study. Toxicon. 2008; 51:934-40.

10. Corringer PJ, Le Novère N, Changeux JP. Nicotinic receptors at the amino acid level. Annu. Rev. Pharmacol. Toxicol. 2000; 40:431-458.

11. Daneshian M, Botana LM, Dechraoui Bottein MY, Buckland G, Campàs M, Dennison N, Dickey RW, Diogène J, Fessard V, Hartung T, Humpage A, Leist M, Molgó J, Quilliam MA, Rovida C, Suarez-Isla BA, Tubaro A, Wagner K, Zoller O, Dietrich D. A roadmap for hazard monitoring and risk assessment of marine biotoxins on the basis of chemical and biological test systems. ALTEX. 2013; 30:487-545.

12. Duroure L, Jousseaume T, Aráoz R, Barre E, Retailleau P, Chabaud L, Molgó J, Guillou C. 6,6Spiroimine analogs of (-)-gymnodimine A : synthesis and biological evaluation on nicotinic acetylcholine receptors. Org. Biomol. Chem. 2011; 9:8112-8118.

13. Espiña B, Otero P, Louzao MC, Alfonso A, Botana LM. 13-desmethyl spirolide-c and 13,19didesmethyl spirolide-c trans-epithelial permeabilities: human intestinal permeability modelling. Toxicology. 2011; 287:69-75. 
14. Fonfría ES, Vilariño N, Molgó J, Aráoz R, Otero P, Espiña B, Louzao MC, Alvarez M, Botana LM. Detection of 13,19-didesmethyl C spirolide by fluorescence polarization using Torpedo electrocyte membranes. Anal. Biochem. 2010; 403:102-107.

15. Gill S, Murphy M, Clausen J, Richard D, Quilliam M, MacKinnon S, LaBlanc P,Mueller R, Pulido O. Neural injury biomarkers of novel shellfish toxins, spirolides: A pilot study using immunochemical and transcriptional analysis. Neurotoxicology 2003; 24:593-604.

16. Guéret SM, Brimble MA. Spiroimine shellfish poisoning (SSP) and the spirolide family of shellfish toxins: Isolation, structure, biological activity and synthesis. Nat. Prod. Rep. 2010; 27:1350-1366.

17. Hauser TA, C.D. Hepler, D.C. Kombo, V.P. Grinevich, M.N. Kiser, D.N. Hooker, J. Zhang, D. Mountfort, A. Selwood, S.R. Akireddy, S.R. Letchworth, D. Yohannes. Comparison of acetylcholine receptor interactions of the marine toxins, 13-desmethylspirolide $\mathrm{C}$ and gymnodimine. Neuropharmacology 2012; 62:2239-2250.

18. Haywood AJ, Steidinger KA, Truby EW, Bergquist PR, Bergquist PL, Adamson J, Mackenzie L. Comparative morphology and molecular phylogenetic analysis of three new species of the genus karenia (dinophyceae) from New Zealand. J. Phycol. 2004; 40:165-179.

19. Hellyer SD, Selwood AI, Rhodes L, Kerr DS. Neuromuscular blocking activity of pinnatoxins E, F and G. Toxicon. 2013; 76:214-20.

20. Hu T, Curtis JM, Walter J A, Wright JLC. Characterization of biologically inactive spirolides E and F: Identification of the spirolide pharmacophore. Tetrahedron Lett. 1996; 37:7671-7674.

21. Jackson JJ, Stivala CE, Iorga BI, Molgó J, Zakarian A. Stability of cyclic imine toxins: interconversion of pinnatoxin amino ketone and pinnatoxin A in aqueous media. J. Org. Chem. 2012; 77:10435-10440.

22. Kharrat R, Servent D, Girard E, Ouanounou G, Amar M, Marrouchi R, Benoit E, Molgó J. The marine phycotoxin gymnodimine targets muscular and neuronal nicotinic acetylcholine receptor subtypes with high affinity. J. Neurochem. 2008; 107:952-963.

23. Lu C-K, Lee G-H, Huang R, Chou H.N. Spiro-prorocentrimine, a novel macrocyclic lactone from a benthic Prorocentrum sp. of Taiwan. Tetrahedron Lett. 2001; 42:1713-1716.

24. MacKinnon SL, Walter JA, Quilliam MA, Cembella AD, Leblanc P, Burton IW, Hardstaff WR, Lewis NI. Spirolides isolated from Danish strains of the toxigenic dinoflagellate Alexandrium ostenfeldii. J. Nat. Prod. 2006; 69: 983-987.

25. McCarron P, Rourke WA, Hardstaff W, Pooley B, Quilliam MA. Identification of pinnatoxins and discovery of their fatty acid ester metabolites in mussels (Mytilus edulis) from Eastern Canada. J. Agric. Food Chem. 2012; 60:1437-1446.

26. Molgó J, Aráoz R, Benoit E, Iorga BI. Physical and virtual screening methods for marine toxins and drug discovery targeting nicotinic acetylcholine receptors. Exp. Opin. Drug Discov. 2013; 8:1203-1223.

27. Molgó J, Aráoz R, Benoit E, Iorga BI. Cyclic imine toxins: chemistry, origin, metabolism, pharmacology, toxicology, and detection. In: Botana LM, editor. Seafood and freshwater toxins. Pharmacology physiology and detection. 3rd ed. CRC Press; 2014: 951-990.

28. Munday R, Towers NR, Mackenzie L, Beuzenberg V, Holland PT, Miles CO. Acute toxicity of gymnodimine to mice. Toxicon. 2004; 44:173-178.

29. Munday, R., Quilliam, M. A., LeBlanc, P. et al., 2012. Investigations into the toxicology of spirolides, a group of marine phycotoxins. Toxins 4: 1-14. 
30. Munday R, Selwood AI, Rhodes L. Acute toxicity of pinnatoxins E, F and G to mice. Toxicon. 2012; 60:995-999.

31. Nézan E, Chromérat N. Vulcanodinium rugosum gen. et sp. nov. (Dinophyceae), un nouveau dinoflagellé marin de la côte Méditerranéenne Française. Cryptogamie, Algologie, 2011; 32 :318.

32. Otero P, Alfonso A, Alfonso C, Aráoz R, Molgó J, Vieytes MR, Botana LM. First direct fluorescence polarization assay for the detection and quantification of spirolides in mussel samples. Anal. Chim. Acta 2011;701:200-208.

33. Otero, P., Alfonso, A., Rodríguez, P. Cifuentes JM, Bermúdez R, Vieytes MR, Botana LM. Pharmacokinetic and toxicological data of spirolides after oral and intraperitoneal administration. Food Chem. Toxicol. 2012. 50:232-237.

34. Richard, D., Arsenault, E., Cembella, A., and Quilliam, M., 2001. Investigations into the toxicology and pharmacology of spirolides, a novel group of shellfish toxins, in Harmful Algal Blooms 2000. Hallegraeff, G. M., Blackburn, S. I., Bolch, C. J., and Lewis, R. J., Ed. Intergovernmental Oceanographic Commission of UNESCO, 383-6.

35. Roach, J. S., LeBlanc, P., Lewis, N. I., Munday, R., Quilliam, M. A., and MacKinnon, S. L., 2009. Characterization of a dispiroketal spirolide subclass from Alexandrium ostenfeldii. J. Nat. Prod. 72: 1237-40.

36. Rhodes L, Smith K, Selwood A, McNabb P, Munday R, Suda S, Molenaar S, Hallegraeff G. Dinoflagellate Vulcanodinium rugosum identified as the causative organism of pinnatoxins in Australia, New Zealand and Japan. Phycologia 2011;50:624-628.

37. Rodriguez, L. P., Vilarino, N., Molgó, J. Aráoz R, Louzao MC, Taylor P, Talley T, Botana LM. Development of a solid-phase receptor-based assay for the detection of cyclic imines using a microsphere-flow cytometry system. Anal. Chem. 2013. 85:2340-2347.

38. Selwood A.I., Wilkins A.L., Munday R., Shi F., Rhodes L.L., Holland P.T. Portimine: A bioactive metabolite from the benthic dinoflagellate Vulcanodinium rugosum. Tetrahedron Lett. 2013; 54:4705-4707.

39. Selwood AI, Wilkins AL, Munday R, Gu H, Kirsty F. Smith KF, Rhodes LL, Rise F. Pinnatoxin H: a new pinnatoxin analogue from a South China Sea Vulcanodinium rugosum isolate. Tetrahedron Lett. 2014; 55:5508-5510.

40. Sixma TK, Smit AB. Acetylcholine binding protein (AChBP): a secreted glial protein that provides a high-resolution model for the extracellular domain of pentameric ligand-gated ion channels. Annu. Rev. Biophys. Biomol. Struct. 2003; 32:311-334.

41. Stivala CE, Benoit E, Aráoz R, Servent D, Novikov A, Molgó J, Zakarian A. Synthesis and biology of cyclic imine toxins, an emerging class of potent, globally distributed marine toxins. Nat Prod Rep. 2015; (in press, DOI: 10.1039/C4NP00089G)

42. Shumway SE. A review of the effects of algal blooms on shellfish and aquaculture. J. World Aquacult. Soc. 1990; 21:65-104.

43. Takada N, Umemura N, Suenaga K, Uemura D. Structural determination of pteriatoxins A, B and C, extremely potent toxins from the bivalve Pteria penguin. Tetrahedron Lett. 2001; 42:3495-3497.

44. Torigoe $\mathrm{K}$, Murata $\mathrm{M}$, Yasumoto $\mathrm{T}$, Iwashita $\mathrm{T}$. Prorocentrolide, a toxic nitrogenous macrocycle from a marine dinoflagellate, Prorocentrum lima. J. Am. Chem. Soc. 1988;110: 7876-7877. 
45. Touzet N, Franco JM, Raine R. Morphogenetic diversity and biotoxin composition of Alexandrium (dinophyceae) in Irish coastal waters. Harmful Algae 2008; 7:782-797.

46. Van der Kloot W, Molgó J. Quantal acetylcholine release at the vertebrate neuromuscular junction. Physiol. Rev. 1994;74:899-991.

47. Van Wagoner RM, Misner I, Tomas CR, Wright JL C. Occurrence of 12-methylgymnodimine in a spirolide-producing dinoflagellate Alexandrium peruvianum and the biogenetic implications. Tetrahedron Lett. 2011; 52:4243-4246.

48. Vilariño N, Fonfría ES, Molgó J, Aráoz R, Botana LM. Detection of gymnodimine-A and 13desmethyl C spirolide phycotoxins by fluorescence polarization. Anal. Chem. 2009; 81:27082714. 